\title{
Clare, Janet.
}

Shakespeare's Stage Traffic: Imitation, Borrowing and Competition in Renaissance Theatre.

Cambridge: Cambridge University Press, 2014. Pp. xi, 305. ISBN 978-1-10704003-8 (hardcover) US\$103.95.

Shakespeare did not work alone; he often collaborated with others. As many as twelve plays traditionally attributed to him show traces of co-authorship. However, while many recent studies of these plays have openly challenged the Romantic myth of Shakespeare's solitary genius, they still tend to treat his contemporaries as only occasional collaborators drawn into the gravitational pull of his brilliance. This is perhaps not surprising in a profession where scholars of Renaissance theatre are divided into Shakespeareans and nonShakespeareans. Shakespeare may not have worked alone, but as Janet Clare reminds us, "Shakespeare studies are often conducted in isolation." Like Bart van Es's Shakespeare in Company (2013), her book thankfully reverses this trend: she does not come to Renaissance theatre through Shakespeare, as their order in the title might imply and her dedication to the Shakespeare Institute might lead one to expect; rather, as a recognized expert in non-Shakespearean drama and an experienced editor of his contemporaries, she comes to Shakespeare with a deep knowledge of and appreciation for the theatrical community in which he worked. The result is a refreshing and timely reflection upon the extent to which Shakespeare's entire writing career might be considered collaborative, not just the plays he co-authored or adapted from other sources.

If Clare's claims for Shakespeare's engagement with his fellow dramatists at times seem simple and obvious, it is only because her arguments for the individual plays she examines are so clearly and persuasively made. In chapter 1, for example, she shows how Shakespeare's Henry V and Richard III were less indebted to the historical sources privileged by editors and commentators, such as Holinshed's Chronicles and Sir Thomas More's History, than they were to the Queen's Men's Famous Victories of Henry the Fifth and True Tragedy of Richard, just as in chapter 2 she shows how Richard II was modelled upon Marlowe's Edward II and an anonymous manuscript play known as Woodstock. That Shakespeare's King John owes much to The Troublesome Reign of King John, another Queen's Men play, also seems likely in light of the fact that it is now widely credited to George Peele, with whom Shakespeare is believed to have 
collaborated on Titus Andronicus at an earlier point in his career. (The "impact" of The Famous Victories appears again as the subject of chapter 5.) In Clare's perceptive view, these plays, and others like them, are for Shakespeare more than just sources; they are distinct commodities or "co-texts" representing competing dramaturgies identifiable with particular authors and playing companies marketing themselves to a specific audience.

By attending to the often overlooked matter of dramaturgy, Clare provides fresh insights to ongoing debates about the relationship between Shakespeare's plays and their nearest sources or analogues, beginning in chapter 3 with the vexing case of the two Shrew plays in which Shakespeare is believed to have had a hand and his adaptation of Plautus's Menaechmi in The Comedy of Errors. The remainder of the book proceeds chronologically from here, comparing $A$ Midsummer Night's Dream with John Lyly's Galatea, The Merchant of Venice with Christopher Marlowe's Jew of Malta, and Twelfth Night with Ben Jonson's Everyman Out of His Humour, in chapter 4; Hamlet with The Spanish Tragedy and John Marston's Antonio's Revenge, in chapter 6; Measure for Measure with George Whetstone's Promos and Cassandra, and King Lear with the anonymous True Chronicle History of King Leir, in chapter 7; and Shakespeare's late romances with John Fletcher's tragicomedies, in chapter 8 . These carefully chosen pairings not only help us better to understand Shakespeare's working relationships, revealing as they do the extent to which theatre was for Shakespeare no less than for his contemporaries "a simultaneously competitive and interactive process." They also help us better to appreciate the works themselves. For as Clare rightfully remarks in the afterword, "[t]he dialogue between Twelfth Night and Every Man Out of His Humour tells us more about Shakespeare's comedy than a study of Twelfth Night alongside The Taming of the Shrew."

If this approach has a fault, it is, as Clare acknowledges, that in many cases " $[t]$ here is no way of knowing for sure the order of composition of the two plays," so that despite the impressive details of her analysis, what she concludes in chapter 3 about the relationship between Shakespeare's Comedy of Errors and a manuscript transcript of Plautus's Menaechmi might be said equally of the volume as a whole: to know any of this for certain is "beyond the bounds of historical re-construction." Some readers might also have a problem with both her "pragmatic approach to the nature of intertextuality," which she defines for her purposes simply as the "interaction between texts," and her even more basic working definition of dialogic as texts "in dialogue," but it is partly by reducing 
terms like these to their "most immediate and accessible understanding" that this study is able so effectively to render visible (and audible) the kinds of "giveand-take" between plays that more theory-focused studies of Renaissance theatre often treat in less detail.

TREVOR COOK

Centre for Reformation and Renaissance Studies

\section{Crousaz, Karine et Solfaroli, Daniela, éds.}

Pierre Viret et la diffusion de la Réforme. Pensée, action, contextes religieux. Collection Histoire Moderne. Lausanne : Éditions Antipodes, 2014. 421 p. ISBN 978-2-88901-054-7 (broché) $29 €$.

Ce volume rassemble dix-huit communications prononcées à Lausanne en septembre 2011 à l'occasion du $500^{\mathrm{e}}$ anniversaire de la naissance du réformateur vaudois Pierre Viret (1511-1571), un auteur francophone de premier plan aux côtés de Jean Calvin et de Guillaume Farel. Ce recueil, qui était attendu et qui ne déçoit pas, rendra désormais difficile de qualifier plus longtemps Viret "de réformateur oublié » («the Forgotten Reformer ») suivant l'expression de Robert D. Linder.

L'édition est bien réussie sur le plan de la qualité scientifique et découle du travail concerté du comité d'organisation du colloque (Irena Backus, Danièle Tosato-Rigo et alter) et de plusieurs autres personnes remerciées dans l'introduction signée par Karine Crousaz et Daniela Solfaroli Camillocci. On regrettera d'emblée, sans le déplorer outre mesure, que certaines études importantes sur Pierre Viret - publiées après la tenue du colloque et avant la parution du présent volume (avril 2014) - ne soient pas mieux intégrées à l'ensemble. Heureusement, le recueil ne passe pas sous silence l'immense étude bibliographique sur Viret réalisée par Dominique-Antonio Troilo (Lausanne : L'Âge d'Homme, 2012) et que Jean-François Gilmont qualifie de magistrale dans sa contribution $(235,253)$. Ces remarques valent aussi pour les travaux de Ruxandra Vulcan et, dans une moindre mesure, pour ceux de Michael Bruening, puisque ce dernier, outre le travail de relecture des traductions des actes qu'il a effectué pour ce recueil, attire l'attention sur ses recherches épistolaires publiées après le colloque, mais avant la présente 